\title{
The European Groupings of Territorial Cooperation Developed by Administrative Structures in Romania and Hungary
}

\author{
Cătălin-SilviU SăRARU
}

\begin{abstract}
This study aims to firstly develop a brief review of the creation and functioning of the European Grouping of Territorial Cooperation (EGTC), highlighting the role of the EGTC in respect of its contribution to the harmonious development of the whole European Union through the strengthening of economic, social and territorial cohesion. The article highlights recent changes in EU legislation governing the EGTC and analyses the influence that there is in choosing the State where a Grouping will be located, and the applicable law. Subsequently, the article outlines the contribution of those EGTCs - constituted by municipalities in Romania and Hungary - to regional sustainable development. Utilising a cross-border EGTC is a way of promoting of better neighbourliness, and stimulating balanced economic development and social stability by harnessing local resources and regional joint projects. At the end of the article I stress the need for cross-border cooperation between Romania and Hungary in developing services of general economic interest, as well as transport infrastructure and tourism.
\end{abstract}

Keywords: European Grouping of Territorial Cooperation (EGTC), territorial cooperation, cross-border governance, municipalities

\section{INTRODUCTION}

The European Grouping of Territorial Cooperation (EGTC) is a legal, non-profit entity, composed of states, regional authorities and local authorities, bodies governed by public law within the European Union with the objective of facilitating and promoting crossborder, transnational and/or interregional cooperation (Spinaci-Vara-Arribas 2009: 5) between its members for the purpose of strengthening the economic, social and territorial cohesion of the European Union.

Establishment and functioning of the EGTC is governed by Regulation no. 1082/2006/ CE of the European Parliament and Council of 5 July 2006 on a European Grouping of Territorial Cooperation - EGTC. ${ }^{1}$ Under the provisions of art. 16 (1) of this Regulation which state that "Member States shall make such provisions as are appropriate to ensure the effective application of this Regulation", Romania adopted the Government Emergency Ordinance No. 127/2007 on a European Grouping of Territorial Cooperation, ${ }^{2}$ approved by the Romanian Parliament by Law. 52/2008. ${ }^{3}$ Hungary adopted the XCIX Act of 2007 on the European Grouping of Territorial Cooperation. ${ }^{4}$

1 Published in the OJEU L 210 of 31 July 2006.

2 Published in the Official Gazette of Romania no. 769 of 13 November 2007.

3 Published in the Official Gazette of Romania no. 230 of 25 March 2008.

${ }^{4}$ In the European Union concerning EGTC national country specific rules see http://www. interact-eu.net/egtc/national_provisions /495/11672, accessed on 5 April 2014.

Cătălin-Silviu Săraru, Lecturer, Ph.D., Bucharest University of Economic Studies, Law Department. E-mail: catalinsararu@yahoo.com

(Received: 29.01.2014; revision received: 26.03.2014; accepted: 14.04.2014.) 
Recently Regulation no. 1082/2006/CE was amended by Regulation no. 1302/2013 of the European Parliament and Council, ${ }^{5}$ the amendments will apply from 22 June 2014. However, according to art. 2 (1) of Regulation no. 1302/2013 EGTCs established before 21 December 2013 shall not be obliged to align their convention and statutes with the provisions of Regulation (EC) No 1082/2006 as amended by this Regulation.

By 26 November 2013 the Committee of the Regions was notified of the establishment within the European Union of 41 EGTCs . ${ }^{6}$

We emphasize that the EGTC was not created as a tool to replace the existing models of cooperation, but this is rather an alternative in addition to other inter-governmental cooperation models available so far (Janssen 2006: 109). Thus, at the European Union level, the cross-border cooperation between Member States and third countries can also be achieved through Euroregions and Eurodistricts. But unlike these structures, the EGTC has legal personality (Zapletal 2010: 18; Duindam-Waddington 2012: 309), thus offering the opportunity to employ staff, have a patrimony and participate in judicial proceedings. This legal stability enhances the decision-making process between partners, their position in terms of interacting with EU institutions and their ability to launch or improve their international position and efficiently manage programs and projects of cooperation (Spinaci-Vara-Arribas 2009: 5-6).

\section{ESTABLISHMENT AND FUNCTIONING OF THE EGTC}

The establishment of an EGTC is optional, and can be done in accordance with the constitutional system of each Member State.

The following entities may become members of an EGTC, according to art. 3 of Regulation no. 1082/2006/CE amended by Regulation no. 1302/2013:

(a) Member States or authorities at the national level;

(b) regional authorities;

(c) local authorities;

(d) public undertakings ${ }^{7}$ or bodies governed by public law; ${ }^{8}$

(e) undertakings entrusted with the operation of services of general economic interest in compliance with the applicable Union and national laws;

(f) national, regional or local authorities, or bodies or public undertakings, equivalent to those referred to under point (d), from third countries, subject to the conditions laid down in Article 3a introduced by art. 1 Section 4 of the Regulation no. 1302/2013.

Associations consisting of bodies belonging to one or more of these categories may also be members.

5 Published in OJEU L-347 of 20 December 2013.

${ }^{6}$ For the List of EGTCs whose establishment has been notified to the CoR in accordance with Regulation (EC) 1082/2006 see https://portal.cor.europa.eu/egtc/en-US/Register/Pages/welcome.aspx, accessed on 5 April 2014.

7 They are provided to point (b) of Article 2(1) of Directive 2004/17/EC of the European Parliament and Council of 31 March 2004 coordinating the procurement procedures of entities operating in the water, energy, transport and postal services sectors (OJ L 134, 30.4.2004, 1).

8 They are provided to the second subparagraph of Article 1(9) of Directive 2004/18/EC of the European Parliament and Council of 31 March 2004 coordinating procedures for the award of public works contracts, public supply contracts and public service contracts (OJ L 134, 30.4.2004, 114). 
An EGTC may be made up of members located in the territory of at least two Member States of the European Union. As an exception to the conditions specified in Art. 3a introduced by art. 1 Section 4 of the Regulation no. 1302/2013, an EGTC may be made up of members located in the territory of only one Member State and one or more third countries neighbouring that Member State, including its outermost regions, where the Member State concerned considers that EGTC to be consistent with the scope of its territorial cooperation in the context of cross-border or transnational cooperation or bilateral relations with the third countries concerned.

In view of establishing an EGTC, the members will draw up and sign the Convention and Statute.

The Convention should include mandatory, according to art. 8 of Regulation no. 1082/2006/CE, as amended by section 10 of Regulation no. 1302/2013 EGTC: the name of the EGTC and its registered office; the extent of the territory in which the EGTC may execute its tasks; the objective and tasks of the EGTC; the duration of the EGTC and the conditions for its dissolution; the list of the EGTC's members; the list of the EGTC's organs and their respective competences; the applicable Union law and national law of the Member State where the EGTC has its registered office for the purposes of interpretation and enforcement of the convention; the applicable Union law and national law of the Member State where the EGTC's organs act; the arrangements for the involvement of members from third countries or from OCTs if appropriate including the identification of the applicable law where the EGTC carries out tasks in third countries or in OCTs; the applicable Union and national law directly relevant to the EGTC's activities carried out under the tasks specified in the convention; the rules applicable to the EGTC's staff, as well as the principles governing the arrangements concerning personnel management and recruitment procedures; the arrangements for liability of the EGTC and its members; the appropriate arrangements for mutual recognition, including financial control of the management of public funds; the procedures for adoption of the statutes and amendment of the convention.

The statutes of an EGTC shall specify, according to art. 9 para. (2) of Regulation no. 1082/2006/CE amended by section 11 of Regulation no. 1302/2013 EGTC, as a minimum, the following: the operating provisions of its organs and those organs' competences, as well as the number of representatives of the members in the relevant organs; its decision-making procedures; its working language or languages; the arrangements for its functioning; its procedures concerning personnel management and recruitment; the arrangements for its members' financial contributions; the applicable accounting and budgetary rules for its members; the designation of the independent external auditor of its accounts; the procedures for amending its statutes.

The Grouping name consists of a name chosen by the members accompanied by "European Grouping for Territorial Cooperation" or "EGTC". The name of an EGTC whose members have limited liability shall include the word 'limited', according to art. 12 of Regulation no. 1082/2006/CE.

The registered office of an EGTC shall be located in a Member State under whose laws at least one of the members is formed. Choosing the State, in which the Grouping will have its registered office, is important in terms of the following issues (Săraru 2013: 355):

- EGTC constitutional documents are prepared, recorded and modified according to the regulations of the State where the Grouping has its registered office. The requirements for the publication of the convention, statutes and accounts of an EGTC whose members have limited liability shall be at least equal to those required for other legal entities with 
limited liability under the laws of the Member State where that EGTC has its registered office.

- In matters relating to Group which are unregulated or only partially covered by the provisions of Regulation, the laws of the Member State where the EGTC has its registered office will be applied.

- Interpretation and application of the Convention and Statute shall be according to EU legislation and the legislation of the Member State where the EGTC has its registered office according to art. 8. (2). g) of Regulation no. 1082/2006/CE, as amended by art. 1, section 10 of Regulation no. 1302/2013.

- Control of an EGTC's management of public funds shall be organised by the competent authorities of the Member State where the EGTC has its registered office. Exceptions include those EGTC actions co-financed by the European Union where the relevant legislation on the control of EU funds is applied and cases whereby authorities of the respective Member State - where the EGTC has its registered office - adopt provisions allowing the competent authorities of other Member States the control of actions taken on their territory by the EGTC in these states, if their national law permits, under art. 6 para. (2) of Regulation no. 1082/2006/CE.

- As regards liquidation, insolvency, cessation of payments and similar procedures, an EGTC shall be governed by the laws of the Member State where it has its registered office, as provided by art. 12 of the Regulation.

- In terms of art. 15 of the Regulation, the EU legislation on jurisdiction shall apply to disputes involving an EGTC. In those cases where such EU legislation does not pertain, the competent courts for the resolution of disputes shall be the courts of the Member State where the EGTC has its registered office. Citizens of Member States of the EGTC retains the right to appeal to the national jurisdictions to exercise appeals against public bodies that are members of an EGTC in respect of: (a) administrative decisions relating to activities which are being carried out by the EGTC; (b) accessing services in their own language; and (c) accessing information.

The objective of an EGTC shall be to facilitate and promote, in particular, territorial cooperation, including one or more cross-border, transnational and interregional strands of cooperation, between its members, with the aim of strengthening Union economic, social and territorial cohesion and overcoming obstacles in the internal market.

In order to achieve the objectives, the EGTC performs the tasks that have been entrusted to its members in accordance with Regulation no. 1082/2006/CE amended by Regulation no. 1302/2013. The EGTC may carry out actions of territorial cooperation between members that have been co-financed by the European Union through the European Regional Development Fund, European Social Fund and / or the Cohesion Fund or selffunding.

The tasks given to an EGTC by its members shall not concern the exercise of powers conferred by public law or duties whereby the object is to safeguard the general interests of the State or other public authorities, such as police and regulatory powers, justice and foreign policy.

Where an EGTC carries out any activity in contravention of a Member State's provisions on public policy, public security, public health or public morality, or is in contravention of the public interest of a Member State, a competent body of that Member State may prohibit that activity in its territory or require those members which have been formed under its law to withdraw from the EGTC unless the EGTC ceases the activity in question. Such prohibitions shall not constitute a means of arbitrary or disguised restriction 
on territorial cooperation between the EGTC's members. Review of the competent body's decision by a judicial authority shall be possible.

The grouping may have a life span determined with an indication of the period expressly or, where appropriate, an unlimited duration.

An EGTC, according to art. 10 of Regulation no. 1082/2006/CE, shall have at least the following managerial, administrative and controlling organs:

(a) an assembly, which is made up of representatives of its members;

(b) a director, who represents the EGTC and acts on its behalf.

The statutes may provide for additional organs with clearly defined powers.

In Europe, the EGTCs contribute to local development through the implementation of projects financed from EU funds, grants from the national governments or from their own funds in order to: enhancing regional economic competitiveness by helping entrepreneurs, creating jobs and promoting the investment (Lille-Kortrijk-Tournai) $;{ }^{9}$ conservation and enhancement of the artistic and cultural heritage; ${ }^{10}$ environmental protection; ${ }^{11}$ promoting the urban ${ }^{12}$ and rural development; ${ }^{13}$ supporting innovation, research and higher education; ${ }^{14}$ improving waste management, ${ }^{15}$ improving medical assistance, ${ }^{16}$ etc.

The EGTCs activity is mainly achieved through:

- identifying the common areas of cooperation and the creation of development programs

- unitary approach to cross border issues through the creation of global strategies for the development

- conducting of the studies to ensure a better response to cross-border issues

- organizing of consultations, debates, conferences, work visits in matters of cross border cooperation

- attracting of the funding sources for projects developed

- facilitating of the management and implementation of the projects.

9 See programs developed by the EGTC Abaúj, Arrabona European Grouping of Territorial Cooperation, Bodrogközi European Grouping of Territorial Cooperation, Eurocidade Chaves - Verín EGTC, the Euroregion Senza Confini EGTC, the Euroregion Pyrenees-Mediterranean EGTC, EGTC TATRY Ltd, The EGTC Lille-Kortrijk-Tournai, https://portal.cor.europa.eu/egtc/en-US/CoRActivities/ Pages/welcome.aspx, accessed on 5 April 2014.

10 See programs developed by European Grouping of Territorial Cooperation Cities of Ceramics, the Espacio Portalet EGTC, https://portal.cor.europa.eu/egtc/en-US/CoRActivities/Pages/welcome. aspx, accessed on 5 April 2014.

11 See programs developed by European Grouping of Territorial Cooperation Duero-Douro, the Parc européen Parco europeo Alpi Marittime - Mercantour EGTC, the ZASNET EGTC, https://portal. cor.europa.eu/egtc/en-US/CoRActivities/Pages/welcome.aspx, accessed on 5 April 2014.

12 See programs developed by European Urban Knowledge Network (EUKN), the EGTC Eurodistrict SaarMoselle, https://portal.cor.europa.eu/egtc/en-US/CoRActivities/Pages/welcome.aspx, accessed on April 5, 2014.

13 See programs developed by the EGTC Karst-Bodva, https://portal.cor.europa.eu/egtc/en-US/ CoRActivities/Pages/ welcome. aspx, accessed on 5 April 2014.

14 See programs developed by the EGTC Euroregion Aquitaine-Euskadi, https://portal.cor. europa.eu/egtc/en-US/CoRActivities/ Pages/welcome.aspx, accessed on 5 April 2014.

15 See programs developed by the Efxini Poli - SolidarCity Network EGTC, https://portal.cor. europa.eu/egtc/en-US/CoR Activities/Pages/welcome.aspx, accessed on 5 April 2014.

16 See programs developed by the Cerdanya Cross-Border Hospital EGTC, https://portal.cor. europa.eu/egtc/en-US/CoRActivities/ Pages/welcome.aspx, accessed on 5 April 2014. 


\section{CONTRIBUTION OF EGTCS ESTABLISHED BY MUNICIPALITIES FROM ROMANIA AND HUNGARY TOWARDS SUSTAINABLE REGIONAL DEVELOPMENT}

Romania and Hungary have established together two EGTC's - Banat-Triplex Confinium Limited Liability EGTC and Gate to Europe Limited Liability EGTC.

Romania and Hungary have officially communicated their intention to establish the Europe - Building Common Future EGTC ${ }^{17}$ in the future. Also the two countries have conducted negotiations for the establishment of the Békés-Arad EGTC. ${ }^{18}$

These EGTCs of cross-border cooperation illustrate the conception by Schamp of "functional regions" - "the territorial cooperation should stay and be based on existing links across borders, which together form the 'functional regions', respectively interdependent territories that do not necessarily coincide with the political and the administrative territorial units outlined by national borders" (Schamp 1995). The functional regions clearly illustrate the link between territorial cooperation and territorial development (Boneva 2011: 68). Border regions are usually located in geographical peripheries of their state and are often more underdeveloped than central regions. Cooperation across borders stimulates development and synergy by encouraging mutual business between regional firms and contacts among local NGOs (Boneva 2011: 68).

The role of regional cross-border cooperation is to foster mutual learning and traditional cultural elements and contribute to increased economic performance and social cohesion (Roper 2007: 554). Implementation of such cooperation depends on the degree of homogeneity in respect of economic, political and institutional conditions, in the administrative structures adjacent to border areas. ${ }^{19}$

Under the influence of EU policies that provide a single economic market by abolishing internal borders and other barriers to trade, economic and social disparities between the border regions of Member States tend to diminish. Cross-border cooperation is no longer strictly an attribute of states - seen as being a traditional quality - to be the sole actors on the stage of international law (Săraru 2011: 107). An important role is played today in cross-border policies by the administrative structures adjacent to border areas, endowed with legal personality, by development associations created by them, and not least by transnational enterprises. ${ }^{20}$

\subsection{Bánát-Triplex Confinium Limited Liability EGTC}

In November 2008 after a conference the idea was born of creating Banat-Triplex Confinium Limited Liability EGTC (BTC EGTC) which was established later on 5 January 2011 as a legal entity with limited liability governed by public law, constituted by an unlimited duration and having its registered office in the Hungarian city of Mórahalom.

17 See EGTC Monitoring Report 2012, European Union, April 2013, https://portal.cor.europa. eu/egtc/en-US/discovertheegtc/Documents/Monitoring\%20Report\%202012/EGTC_ MonitoringReport_2012.pdf, 97, accessed on 5 April 2014.

18 Idem, 98.

19 For an analysis of factors to promote the cross-border cooperation among the countries of South-Eastern and Central Europe (Alexandru 1999: 733-736; Stan 2008; Ibreljic-Kulenovic 2004; Dimitrov-Tsiapa-Petrakos 2003: 5-25; Larion-Nedelea-Elmazi 2008: 44-49)..

20 See for global reconsideration of the role of the states under the influence of the construction of the European Union: (Alexandru 1999: 733-736; Stan 2008; Ibreljic-Kulenovic 2004; DimitrovTsiapa-Petrakos 2003: 5-25; Larion-Nedelea-Elmazi 2008: 44-49). 
Banat-Triplex Confinium Limited Liability EGTC's members are ${ }^{21} 37$ local authorities from Hungary, ${ }^{22} 37$ local authorities from Romania ${ }^{23}$ and eight localities from Serbia as observing members. ${ }^{24}$ In 2012, the Hungarian municipalities Csengele, Kistelek, Zákányszék and the Romanian municipalities of Foeni, Giulvăz, Sag also joined at the Grouping.

The Bánát-Triplex Confinium EGTC involves 342,000 inhabitants in a 3,500 km²'s area.

Governing bodies of the BTC EGTC are: the General Assembly comprising all members, the Chairman, the Board of Directors composed of five members, and the Supervisory Board.

The BTC EGTC was set up to enhance the dynamism of the border areas and to raise their competitiveness through economic and social cohesion activities in agricultural innovation, renewable energy resources, infrastructure, education and training. The main purpose of the EGTC is the implementation of programs or projects, for territorial cooperation co-financed by the European Union through the European Regional Development Fund, European Social Fund and / or the Cohesion Fund.

In 2012, the budget of the Bánát-Triplex Confinium EGTC was 34,000 EUR. ${ }^{25}$ It was financed by membership fees to cover operations. EU funding and Hungarian subsidies may also form part of the budget.

The precondition for an operational structure is the availability of funding. The financial endowments of EGTCs reveal huge differences across Europe depending on the numbers of inhabitants of the areas covered as well as the economic standing of the regions involved. Eurométropole Lille-Kortrijk-Tournai, with a comparatively large annual budget of about EUR 1.5 million, stands next to a large group of EGTCs (about one third of all groupings) that have annual budgets ranging between EUR 25,000 and 75,000. ${ }^{26}$

${ }^{21}$ For a description of the administrative-territorial component, see http://www.btc-egtc.eu/en/ - local governments.

${ }^{22}$ Local authorities, members of Hungary are: Apátfalva, Ambrózfalva, Ásotthalom, Bácsborsód, Bordány, Csanádalberti, Csanádpalota, Csikéria, Domaszék, Ferencszállás, Forráskút, Földeák, Gara, Kelebia, Királyhegyes, Kiskunhalas, Kiszombor, Klárafalva, Kövegy, Kunbaja, Madaras, Magyarcsanád, Makó, Maroslele, Mórahalom, Nagyér, Nagylak, Óföldeák, Öttömös, Pitvaros, Pusztamérges, Röszke, Ruzsa, Tompa, Újszentiván, Üllés.

${ }^{23}$ Local authorities, members of Romania are: Banloc, Beba Veche, Birda, Cărpinis, Cenad, Cenei, Checea, Ciacova, Comloşu Mare, Denta, Dudestii Vechi, Deta, Gataia, Ghilad, Giera, Gottlob, Iecea Mare, Jamu Mare, Jebel, Jimbolia, Lenauheim, Liebling, Livezile, Lovrin, Moravita, Nitchidorf, Otelec, Periam, Pesac, Sacalaz, Sanmihaiu Roman, Sannicolau Mare, Sanpetru Mare, Tomnatic, Uivar, Varias, Voiteg.

${ }^{24}$ The observing members from Serbia are: Ada, Zitiste, Čoka, Kanjiža, Novy Kneževac, Senta, Nova Crnja, Kikinda.

25 See the portal European Grouping of Territorial Cooperation - https://portal.cor.europa.eu/ egtc/en-US/CoRActivities/Pages $/ \mathrm{B} \% \mathrm{C} 3 \% \mathrm{~A} 1 \mathrm{n} \% \mathrm{C} 3 \% \mathrm{~A} 1 \mathrm{t}-$ Triplex-Confinium.aspx, accessed on 5 April 2014.

${ }^{26}$ See EGTC Monitoring Report 2012, European Union, April 2013, https://portal.cor. europa.eu/egtc/enUS/discovertheegtc/Documents/Monitoring\%20Report\%202012/EGTC_Monitoring Report_2012.pdf, 88, accessed on 5 April 2014 
Since 2012, the Bánát-Triplex Confinium EGTC implemented several cross-border cooperation projects: ${ }^{27}$

- "Updating of the development strategies of local municipalities and creation of cross-border common sectorial development operational programmes and projects". This project aimed to constitute a modern, developed and competitive economy at the border region, with a 99,800 EUR's budget (85\% EU funding).

- "Content development of the SMEs related services and the establishment and operation of a unified business development network" aimed at creating cooperative opportunities for SMEs, through the development of an agrarian network and a food industry with transport and storage infrastructure. The total budget of the project was EUR 90,128 (85\% EU funded). From March 2013 to March 2014.

- The project "Dance and Music without borders" organised several events along the border areas. Total budget of EUR 87,771 (85\% EU funded).

- "Strengthening co-operation and network resources in favour of achieving economic growth" was a project supporting the creation of business cooperation, with a total budget of 75,770 EUR (ERDF + National contribution EUR 71,981.96; EGTC contribution EUR 3,788.52). From 1 March 2012 to 28 February 2013.

- The project "ExpoTrain SME" organised cross-border Expo and Training Sessions to empower SMEs, with total budget of 87,771 EUR (EU contribution of EUR 74,605.35, EGTC contribution EUR 8,764.05). From 1 March 2013 to 28 February 2014.

- The project "0041 ETT", with a budget of 5,000,000 HUF by the Hungarian Ministry of Justice. From 1 November 2011 to 31 May 2012.

So, thanks to the involvement of members of the BTC EGTC economic and cultural projects were developed in a short period of time, which is a promising start. However, to have sustainable economic development in the border area, it is necessary to develop primary transport infrastructure, education and the exploitation of renewable energy resources. The transboundary EGTC offers the chance - through joint programs financed by the EU - for infrastructure to be created and / or upgraded which will in turn be the engine of economic development.

\subsection{Gate to Europe Limited Liability EGTC}

The founding members of the Gate to Europe EGTC include the municipalities of Nyíradony, Derecske, Hajdúhadház, Újfehértó (Hungary) and Săcueni, Valea lui Mihai, Cherechiu and Carei (Romania). The final decision of the Court of Budapest, regarding the establishment of the EGTC was given on 4 May 2012. The Gate to Europe EGTC was established as a legal entity with limited liability governed by public law, constituted by unlimited duration and having a registered office in the Hungarian city, Nyíradony.

The management bodies of the Grouping are: the General Assembly composed of eight mayors who are responsible for making decisions for the EGTC; the Supervisory Committee composed of three mayors responsible for controlling the financial activities of the EGTC. This committee meets once a year.

The Gate to Europe EGTC involves around 88,000 inhabitants in a $808.78 \mathrm{~km}^{2}$ area.

27 See the portal European Grouping of Territorial Cooperation - https://portal.cor.europa.eu/ egtc/en-US/CoRActivities/Pages/ B\%C3\%A1n\%C3\%A1t-Triplex-Confinium.aspx, accessed on 5 April 2014. 
In future the EGTC wants cooptation of new municipalities in Hungary (Újléta village; Álmosd village; Téglás city; Nyírmártonfalva village; Nyíracsád village) and Romania (Tasnad city; Marghita city; Curtuiseni village; Beltiug village; Diosig city, Simian village). ${ }^{28}$

The EGTC was created as a platform for mayors to work together on joint cross-border projects and programmes. These activities are based on integral territorial investment (ITI).

The Gate to Europe EGTC aims to reinforce economic and social cohesion between its members as part of cross-border cooperation and implement regional development plans and projects. The main sector of activities is tourism.

In future the Gate to Europe EGTC aims to develop policies that will provide young local entrepreneurs with new skills, create an agricultural organisation that addresses fragmentation of lending in the area, and develop recognised brands in the area. ${ }^{29}$

In 2012, the budget of the Gate to Europe EGTC was 16 Million HUF (approximately 54,000 EUR)..$^{30}$

Between January 2, 2012-May 31, 2012 the Gate to Europe EGTC received the program "Aid budgetary for the European Territorial Associations" conducted by the Local Administration of Nyíradony town. ${ }^{31}$

The Gate to Europe EGTC has not implemented any EU-funded project yet. However, it is planning to participate in the European Territorial Cooperation Hungary-Romania Program (ETC HU-RO), the South-East Europe Program (SEE TCP) and the Danube Strategy. ${ }^{32}$

We observe, therefore, that there is a desire to achieve sustainable joint development programs, but we appreciate that this will not be achieved in the near future without the implementation of EU-funded projects and without the attracting of new members in the border region that would increase the administrative capacity required for implementation of tourism programs, agricultural programs, etc.

28 See EGTC Monitoring Report 2012, European Union, April 2013, https://portal.cor.europa. eu/egtc/en-US/discovertheegtc/ Documents/Monitoring\%20Report\%202012/EGTC_MonitoringReport 2012.pdf, 23, accessed on 5 April 2014.

29 Ibidem.

30 See the portal European Grouping of Territorial Cooperation - https://portal.cor.europa.eu/ egtc/en-US/CoRActivities/Pages/ Gate-to-Europe.aspx, accessed on 5 April 2014.

${ }^{31}$ See the site Gate to Europe EGTC - http://ro.europakapu.eu/Proiecte, accessed on 5 April 2014.

32 See the portal European Grouping of Territorial Cooperation - https://portal.cor.europa.eu/ egtc/en-US/CoRActivities/Pages/Gate-to-Europe.aspx, accessed on 5 April 2014. 


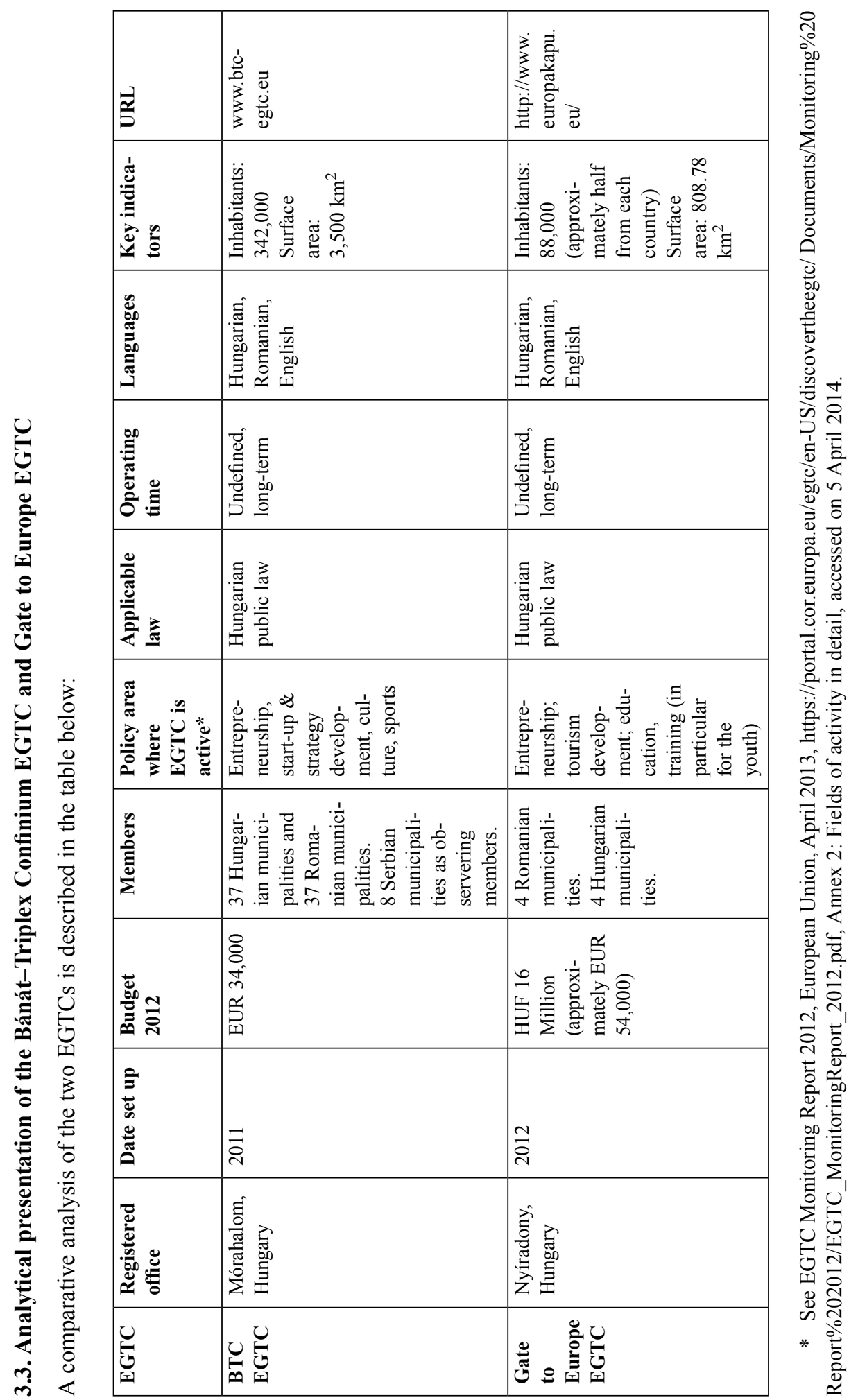


We observe that the two EGTCs both have registered offices in Hungary, they are constituted by an indefinite period and exist under the rules of public law in Hungary. Establishing of the EGTC registered office in Hungary determines, under the provisions of Regulation no. 1082/2006/CE amended by Regulation no. 1302/2013, the application of Hungarian public law regarding: preparation, modification and interpretation of the EGTC constitutional documents; controlling the management of public funds used by EGTC; the dissolution and liquidation procedures; resolving issues related to Group unregulated or only partially covered by the provisions of the EU Regulation; disputes involving EGTC in cases not covered by EU law and by the jurisdiction of the Court of Justice of the European Union.

Furthermore, both EGTCs have as their official languages Hungarian, Romanian and English and both have presentation sites.

On the other hand, the Bánát-Triplex Confinium EGTC has more experience due to it being established a year earlier and - as it consists of a greater number of members - it represents a greater number of people and larger territorial area. Despite this, we note that the Gate to Europe EGTC, benefiting from the "Aid budgetary for the European Territorial Associations" managed to have a bigger budget than the Bánát-Triplex Confinium EGTC. This emphasizes the need for involving the financial strength of regional municipalities (cities, districts) to contribute to the budget of the EGTC.

\section{CONCLUSIONS}

The EGTC is designed to help simplify the process of territorial cooperation at the borders of Member States by providing a clear and coherent framework for interventions at local, regional and national levels, and preventing constitutional, legal and financial barriers.

The two EGTCs set up by local authorities in Romania and Hungary - Bánát-Triplex Confinium EGTC and Gate to Europe EGTC - are just starting out. As time passes, Romania and Hungary should establish a network of EGTCs including the members of all administrative units in the border area (villages, towns, counties) and seeking finances from the structural funds of the European Union (European Regional Development Fund, European Social Fund, Cohesion Fund) to develop joint programs that contribute to improving transport infrastructure, the protection of natural resources, transport and the production infrastructure of energy, health care centres', programs enhancing tourism potential.

The EGTCs with an older history have developed outstanding programs through EU funds. Thus, it is worth mentioning the "CreaMed" project developed by the Euroregion Pyrenees-Mediterranean EGTC formed by the Mediterranean regions from France and Spain. With a budget of 1.3 million euros, of which $75 \%$ EU Contribution, this project was developed between 2010-2012 and contributed to promote the Mediterranean industry by developing innovative and creative techniques in Mediterranean companies and led to growth in the area. ${ }^{33}$

The EGTCs experience with an older history shows that for access to the consistent financial sources should be attracted in addition to the villages and cities also greater administrative territorial units (border counties). We also recommend the creation of

${ }^{33}$ For details about this project see http://www.creativity4med.eu/, accessed on 5 April 2014. 
programs through which the cross-border EGTCs be supported by the governments of the two countries by providing financing from the national budgets.

Under the terms of Regulation no. 1302/2013 EGTC the members of an EGTC will pursue undertakings responsible for providing services of general economic interest. Therefore, it opens the way for an EGTC to be used in the future to jointly manage public services, with a particular focus on services of general economic interest or infrastructure. Consequently, public or private undertakings that provide services of general economic interest alone or through associations [e.g. the intercommunity development associations with the object of activity public utility services ${ }^{34}$ in Romania] could become members of the EGTC, thus extending the cross-border and interregional cooperation in education and training, health care, social works related to health and long-term care, childcare, labour market access and reintegration, social housing, support and the social inclusion of vulnerable groups, etc. Thus knowledge transfer at the level of best practice could be achieved, and would reduce development disparities between different cross-border communities.

Finally, we emphasize that the cross-border EGTCs, facilitating a "reallocation of authority" (Alexandru 2008: 903) from the state level to local administrative units' adjacent border areas, can lead to a mitigation of regional imbalances. Thus, EGTCs are a way of promoting good neighbourliness, stimulating balanced economic development and social stability by building local and regional resources in joint projects.

\section{REFERENCES}

Alexandru, I. (coord.) (1999): Drept administrative. Omnia, Braşov.

Alexandru, I. (2008): Tratat de administraţie publică. Universul Juridic, Bucharest.

Apostol-Tofan, D. (2006): Institutiile administrative europene, C. H. Beck, Bucharest.

Boneva, S. (2011): The Danube Strategy and the Energy Security of the Danube Macro Region. The DRC Summer School on Regional Co-operation, Proceedings.

Dimitrov, M.-Tsiapa, M.-Petrakos, G. (2003): Cross-Border Cooperation in South-Eastern Europe. East European Economics, 41(6).

Duindam, S.-Waddington, L. (2012): Cross-Border Cooperation in the Rhine-Meuse Region: Aachen (D) and Heerlen (NLs). Some Considerations from a Law and Economics Perspective on a Future European Grouping of Territorial Cooperation. European Journal of Law and Economics, 33(2)

Ibreljic, I.-Kulenovic, S. (2004): Economic Regional and Cross-Border Cooperation in SouthernEast Europe for the Purpose of its Faster Integration in the European Union. 44th Congress of the European Regional Science Association Porto, Portugal 25-29 August, 2004. Paper provided by European Regional Science Association in its series ERSA conference papers, http://ideas. repec.org/p/wiw/wiwrsa/ersa04p224.html.

Janssen, G. (ed.) (2006): Europäische Verbünde für territoriale Zusammenarbeit (EVTZ) (European Grouping of Territorial Cooperation - EGTC). Berlin (Juristische Schriftenreihe).

Larion, A.--Nedelea, M.-O.-Elmazi, L. (2008): The Process of EU Integration, Regional Development and Cross Border Cooperation, "The Annals of the 'Stefan cel Mare' University of Suceava. Fascicle of The Faculty of Economics and Public Administration", 8(1)

Roper, S. (2007): Cross-Border and Local Co-Operation on the Island of Ireland: An Economic Perspective, Political Geography, 26(5) 
Săraru, C.-S. (2013): Cartea de contracte administrative. Modele. Comentarii. Explicații, C.H. Beck, Bucharest.

Săraru, C.-S. (2005): Spaţiul administrativ European (European Administrative Space) in Alexandru, I. et al.: Drept administrativ European (European Administrative Law). Bucharest: Lumina Lex.

Săraru, C.-S. (2011): The Cross-Border Cooperation Agreement, Juridical Tribune, 1(1).

Schamp, E. W. (1995): Die Bildung neuer grenzüberschreitender Regionen im östlichen Mitteleuropa

- eine Einführung. In: Gruber, G.-Lamping, H.-Schamp, E. W. (eds.) (1995): Neue grenzüberschreitende Regionen im östlichen Mitteleuropa. Frankfurt (Main). Selbstverlag Institut für Wirtschafts- und Sozialgeografie der J.-W.-Goethe Universität.

Spinaci, G.-Vara-Arribas, G. (2009): The European Grouping of Territorial Cooperation (EGTC): New Spaces and Contracts for European Integration? EIPASCOPE (2).

Stan, D. (2008): La règlementations juridique de la cooperation transfrontalière, dans les documents internationales de la Roumanie signes avec ses voisins (I) and (II). International Law Notebooks, (2-3)

Zapletal, J. (2010): The European Grouping of Territorial Cooperation (EGTC): A New Tool Facilitating Cross-Border Cooperation and Governance. Quaestiones Geographicae, 29(4). 